\title{
O homem duplicado: reminiscências e intertextualidades
}

\author{
Thárea Raiza Hernandes*
}

\begin{abstract}
Resumo: José Saramago se destaca dentre os escritores, por apresentar uma narrativa complexa e densa com muitas possibilidades de sentido e ação, atraindo o leitor para dentro do texto com a apropriação dos fatos e entendimento da realidade extratextual. O autor, valendo-se das características presentes na Post-Modernidade, recria o mundo ficcional revitalizando os sentidos e a construção textual pela produção de intertextos. Assim, pretendemos mostrar como em $O$ homem duplicado (2002), Saramago dá um novo sentido ao já usado pela literatura tradicional e conhecido pelo leitor, que deve ficar atento ao texto, principalmente, pelo uso feito da linguagem, que apresenta várias possibilidades de entendimento, devido à pontuação.
\end{abstract}

Palavras-chave: Post-Modernismo; duplicado; intertextualidade;

O homem metaficção;

\begin{abstract}
José Saramago distinguishes himself among writers by presenting a complex and dense narrative with many possibilities of meaning and action, attracting the reader to the text with the appropriation of facts and the understanding of the extra-textual reality. Having at hand the characteristics of the Post-Modernism, the author recreates the fictional world revitalizing the meanings and the textual construction through the production of intertexts. Thus, we intend to show how Saramago, in $O$ homem duplicado (2002), gives a new meaning to that already used by the traditional literature and already known by the reader, who must pay close attention to the text, due mainly to the use of the punctuation, which allows several possibilities of understanding.
\end{abstract}

Keywords: Post-Modernism, O homem duplicado, intertextuality, metafictional, metalanguage. metalinguagem.

A Pós-Modernidade ocupa um cenário amplo de questões sociais e culturais e deixa para a Literatura o período específico do Pós-Modernismo que se relaciona com o Modernismo literário. Entretanto, devemos atentar para o fato de que se esse movimento pósmoderno faz realmente uma ruptura com os anteriores ou mantém uma relação de continuidade, tanto com pontos positivos quanto negativos.

Seguindo esse questionamento, Ana Paula Arnaut (2002), em Post-modernismo no romance português contemporâneo, propõe utilizarmos o termo 'Post', dando a ideia de manutenção de relação com o passado, pois, segundo ela, o termo "Pós" expressaria uma ruptura total com escolas literárias anteriores, o que parece não ocorrer evidentemente nas obras literárias contemporâneas. Portanto, com esse Post-Modernismo, temos uma colcha de retalhos que estabelece a ligação entre o passado e o presente, fazendo surgir um movimento literário que não cria algo novo, mas o faz de uma nova maneira.

\footnotetext{
* Licenciada plena e Bacharel em Português/Grego pela Universidade Estadual Paulista "Julio de Mesquita Filho"- Campus Araraquara. Mestranda em Estudos Literários pela mesma universidade.
} 
Esse movimento mistura gêneros ou subgêneros, conduzindo a uma polifonia textual, já existente em outros movimentos literários, mas que agora tem suas costuras à mostra. Além disso, cria uma metaficção, chamando a atenção para o fato de ser uma obra literária, o que ocasiona a suspensão voluntária da crença no texto devido à manipulação do autor.

A literatura portuguesa contemporânea tem, pois, apresentado autores de tendências diversas que convergem para o denominador comum de renovação profunda do romance, revelando transformações de formas, textualização e acompanhamento da mudança dos tempos. A partir da textualização do romance há o desenvolvimento da problemática do outro em diferentes níveis (discurso, gênero, narrador), fazendo com que o romance volte para si mesmo (construção do romance no romance), se questionando e se explicando pela pluridiscursividade e autorreflexividade.

Dessa forma o texto se constrói com a ajuda do leitor, que passa a ser inserido no contexto de interações, fundindo as expectativas do emissor e do receptor, o que realça o experimentalismo dessa ficção. Com isso percebemos a preocupação do romance português contemporâneo em incorporar o mundo, fragmentário e múltiplo, na constituição do texto e do discurso para representar a realidade inquietante.

Essa realidade incerta que toma conta do romance é traduzida pelos contrastes estabelecidos entre autores, textos, visões de mundo, entre outros, tornando o tex to polifônico. Assim, o romance pretende representar a natureza enigmática do homem inserido na realidade indeterminável, que tem seus valores, em mudança, refletidos no discurso ficcional.

É notável, no movimento ainda, o conflito entre História e Literatura, pois os estudos post-modernos problematizam a narrativa histórica, questionando se essa mantém um distanciamento com o texto literário, fato que não acontece realmente. Segundo Umberto Eco:

\footnotetext{
A resposta pós-moderna ao moderno consiste em reconhecer que o passado, como não pode ser realmente destruído porque sua destruição conduz ao silêncio [a descoberta do modernismo], precisa ser reavaliado: mas com ironia, e não com inocência. (ECO apud HUTCHEON, 1991, p.124).
}

É dessa maneira que a metaficção historiográfica retoma temas históricos e brinca com suas verdades. Com isso, o Post-Modernismo reescreve a História deslegitimando as grandes narrativas, principalmente através da paródia, e reescrevendo a história pela metaficção, além da História oficial a partir de documentos não considerados e do ponto de vista dos esquecidos da classe social mais baixa. Essa retomada histórica pela literatura, vinda do NeoRealismo, conduz a ideia de uma obra aberta, com várias possibilidades interpretativas, induzindo a uma série de leituras possíveis. 
Esse tipo de construção aliada ao tratamento dado à linguagem, que pode se tornar confusa em alguns momentos, pois reflete a fragmentação do mundo e do homem, além do texto polifônico, acaba tornando a literatura contemporânea difícil. A arte não quer mais agradar, mas colocar problemas e questionamentos para renovar a percepção no modo de ver as coisas e o mundo, criando um desconforto e exigindo esforço do leitor para perceber as dubiedades do texto e sua mensagem.

Angústia, sofrimento, solidão e medo são temas frequentes no romance contemporâneo para expressar a fragilidade do homem diante da queda de antigos valores e também para intensificar os conflitos, ambiguidades e os questionamentos da verdade. $\mathrm{O}$ romance retrata a sociedade, lutas político-sociais, o homem dilacerado e o mundo dividido entre essência e aparência, que são mimetizados pala estrutura fragmentada do próprio discurso ficcional.

José Saramago, autor representativo da literatura portuguesa contemporânea, em suas obras, utiliza o texto fragmentado e a intertextualidade, com diferentes registros, tanto históricos quanto ficcionais; dá importância ao tratamento com a linguagem, questiona a obra literária no próprio texto, utiliza a polifonia e trabalha com outros elementos da literatura moderna que exige atenção do leitor para o entendimento da mensagem. A composição dos romances saramaguianos nos permite viver as experiências do texto como a memória, observação de fatos e articulação e construção de um universo de representações, com seres ficcionais densos, construídos através de questões religiosas, históricas, psicológicas e míticas.

Em O homem duplicado (2002) o autor alia a forma ao conteúdo, trabalhando a linguagem com uma diferente maneira de pontuação, fazendo intertextualidades interna e externa à obra, além de retomar a discussão entre história individual e história ficcional e a problematização da História portuguesa.

A narrativa desse romance nos mostra um professor de História, chamado Tertuliano Máximo Afonso, que vive sozinho sem grandes expectativas, mas que tem sua vida mudada a partir do momento em que assisti ao filme chamado "Quem porfia mata caça" e vê uma personagem que é sua cópia fiel. O professor descobre quem é o ator e arma uma situação para encontrá-lo, colocando-se diante de um impasse e revelando-se um homem com dificuldades de se apropriar do que lhe pertence.

O Homem duplicado (2002) é uma obra na qual Saramago faz uma retomada paródica de textos clássicos, tanto no enredo, que remete à Guerra de Troia, quanto na forma que indica elementos da tragédia clássica, como oráculo, destino e coro. O texto reúne os 
principais conceitos do post-modernismo: a paródia, o uso de vários níveis da linguagem, a intertextualidade, a metalinguagem e metaficção historiográfica, tornando a arte contraditória e duplicada.

Nessa obra, Saramago também faz intertextualidade com o discurso popular, pelo uso da linguagem e de ditados populares, e com o estilo literário, presentes em $O$ Delfim, metaficção historiográfica de José Cardoso Pires. Essa intertextualidade se dá através da metáfora da lagartixa, que, em Cardoso Pires, aparece como representação do tempo estagnado em Portugal e é retraduzida por Saramago.

A referência é feita de forma irônica, pois a 'nova' lagartixa representa a História cortada, mas que se regenera ao longo do tempo e possui muitos fatos excluídos da versão oficial. Assim, Tertuliano representa a história dos colégios:

\begin{abstract}
A História que Tertuliano Máximo Afonso tem a missão de ensinar é como um bonsai a que de vez em quando se aparam as raízes para que não cresça, uma miniatura infantil da gigantesca árvore dos lugares e do tempo [...] nem sequer um diminuto beija-flor, conseguiria fazer ninho nos ramos de um bonsai, e se é verdade que a sombra deste, supondo-o provido de suficiente frondosidade, pode ir acoitar-se uma lagartixa, o mais certo é que ao réptil lhe fique a ponta do rabo de fora. A História que Tertuliano Máximo Afonso ensina, ele mesmo o reconhece e não se importará de confessar se lho perguntarem, tem uma enorme quantidade de rabos de fora, alguns ainda remexendo, outros já reduzidos a uma pele encarquilhada como uma carreirinha de vértebras solta dentro. (SARAMAGO, 2002, p.15-16).
\end{abstract}

Dessa forma, o texto introduz o conflito entre História e Literatura, retomando as questões post-modernas que problematizam a narrativa histórica, questionando o quanto ela se distancia da Literatura e mantém uma forte ligação com a História oficial, não valorizando a todos que a fizeram. Assim, como em outros livros, Saramago utiliza a intertextualidade com ironia, justamente para questionar a verdade histórica.

Como dito anteriormente, a estética post-moderna como o conceito de 'contramodelo' cria uma narrativa aberta e polifônica, garantindo uma variada possibilidade interpretativa feita pelo leitor. Nesse texto, percebemos que o estilo usado pelo autor segue os preceitos do movimento, tornando-o complexo e multifacetado, principalmente pela maneira de pontuar de Saramago que conduz a várias leituras.

A pontuação utilizada, que não correspondente à forma tradicional, causa um embate com o leitor, principalmente porque é feita, em sua maioria, por vírgula, quase não apresentando ponto final, mesmo que haja o surgimento de uma letra maiúscula que pode aparecer no meio da frase sem apresentar nenhum problema. O único impasse criado será para o leitor desatento que espera encontrar um texto nos moldes tradicionais. 
Vemos então, um autor que não está preocupado em seguir a norma gramatical, mas que prefere instigar o leitor, causando-lhe confusão e chamando-o a uma escolha individual, no meio de tantas interpretações que o texto proporciona. $\mathrm{O}$ autor quer nos colocar diante dos problemas, renovando nossas percepções diante do mundo e fazendo-nos perceber as dubiedades da vida e do texto.

Entretanto, predomina no texto um narrador em terceira pessoa que devido a sua onisciência, com a qual expressa sua opinião sobre as personagens, conduz a certa perda da multiplicidade do texto, fazendo com que o leitor não tenha de imaginar o que acontece, pois tudo, inclusive pensamentos, é revelado pelo narrador. Com esse tipo de narrador, o autor tenta manter não só a sua imparcialidade, como também a do leitor, diante de duas personagens iguais fisicamente, mas diferentes na maneira de agir e viver. No entanto, ao longo do texto, é dado maior espaço para o discurso direto, fazendo com que o leitor entre em contato diretamente com as personagens.

Com o uso de discurso direto, o autor nos proporciona uma obra múltipla, pois não faz marcação de começo e fỉm das falas, gerando confusão no momento de atribuí-las às personagens.

[...] Imagine um cesto de laranjas, disse o outro, imagine que, uma delas, lá no fundo, começa a apodrecer, imagine que, uma após a outra, vão todas podrecendo, quem é que poderá, nessa altura, pergunto eu, dizer onde a podridão principiou, Essas laranjas a que está a referir-se são países, ou são pessoas, quis saber Tertuliano Máximo Afonso, Dentro de um país, são as pessoas, no mundo são os países, e como não há países sem pessoas, por elas é que o apodrecimento começa, inevitavelmente, E por que teríamos tido de ser nós, eu, você, os culpados, Alguém foi, Observo-lhe que não está a tomar em consideração o factor sociedade, A sociedade, meu querido amigo, tal como a humanidade, é uma abstração, Como a matemática, Muito mais que a matemática, ao pé delas a matemática é tão concreta como a madeira desta mesa, Que me diz, então, dos estudos sociais, Não é raro que os chamados estudos sociais sejam tudo menos estudos sobre as pessoas, Livre-se de que o ouçam os sociólogos, condenálo-iam à morte cívica, pelo menos, [...] (SARAMAGO, 2002, p.39).

Outra característica post-moderna da obra é a utilização da metalinguagem, em que o autor discute e revela sua preocupação com o estudo da linguagem, principalmente a popular, que assume um papel relevante no texto. $\mathrm{O}$ narrador começa fazendo um panorama sobre a criação da linguagem e de como ela faria falta senão pudéssemos dizer nada.

[...] Houve um tempo em que as palavras eram tão poucas que nem sequer as tínhamos para expressar algo tão simples como Esta boca é minha, ou Essa boca é tua, e muito menos para perguntar Por que é que temos as bocas juntas. Às pessoas de agora não lhes passa pela cabeça o trabalho que deram a criar estes vocábulos, em primeiro lugar, e quem sabe se não terá sido, de tudo, o mais difícil, foi preciso perceber que havia necessidade deles, depois hou vê que chegar a um consenso sobre o significado dos seus efeitos imediatos, e finalmente, tarefa que nunca viria a concluir-se por completo, imaginar as consequiências que poderiam advir, a médio e a longo prazo, dos ditos efeitos e dos ditos vocábulos. [...] (SARAMAGO, 2002, p.61). 
Após essa discussão, nos é apresentado um diálogo entre os professores, que falam sobre os significados de expressões populares e de como elas eram usadas no âmbito familiar de cada um, concluindo que há grande variação linguística no uso dessas expressões.

[...] Meu caro, não vale a pena enxofrar-se, o assunto não tem importância, [...], Que significa exactamente enxofrar-se, perguntou a professora de Literatura, tanto por curiosidade como para deitar água na fervura, Enxofrar-se, respondeu o de Matemática, significa irritar-se, zangar-se, ou, com mais precisão, arrufar-se, E por que é arrufar-se, em minha opinião, mais preciso que zangar-se ou irritar-se, perguntou o professor de Ciências Naturais, Não será mais que uma interpretação pessoa que tem que ver com recordações da infância, quando minha mãe me repreendia ou castigava por qualquer tropelia eu fechava a cara e recusava-me a falar, mantinha um silêncio total que podia durar muitas horas, então ela dizia que eu estava arrufado, Ou enxofrado, Exactamente, Em minha casa, quando eu andava por essas idades, disse a professora de Literatura, a metáfora para os amuos infantis era diferente, Diferente, em quê, Digamos que asinina, Explique-nos lá isso, Amarrar o burro, era o que se dizia, e escusam de ir procurar a expressão nos dicionários porque não a encontram, suponho que fosse exclusiva da família. [...] (SARAMAGO, 2002, p.144).

Além disso, linguagem presente no texto mantém o nível coloquial pelo uso de redundâncias, típicas da linguagem falada: “[...] Também o senhor não o conhece a ele, [...]” (SARAMAGO, 2002, p.177).

Com isso, notamos que Saramago busca o uso de uma linguagem tipicamente popular, seguindo os preceitos do post-modernismo de usar os dialetos, que não estão conforme a gramática tradicional e culta, nos textos literários. Para isso, o autor também faz uso de ditados populares que ao longo do texto não são facilmente identificáveis por serem expressões típicas de Portugal, mas que se lidos atentamente, contribuem para uma melhor percepção do romance.

O primeiro ditado que aparece é o nome do filme, no qual Tertuliano descobre seu sósia, "Quem porfia mata caça", que se assemelha ao brasileiro "Quem espera sempre alcança”. Esse ditado faz referência ao próprio Tertuliano, que obstinado e angustiado, não mede esforços para descobrir sobre seu sósia e acaba atraindo problemas para si mesmo, agindo contra a ordem natural das coisas, ou seja, contra o seu destino, tentando construir sua própria história e por isso caindo em desmedida e merecendo uma punição.

Dessa forma, temos uma narrativa cheia de interrogações, em que um homem, entre o seu marasmo e sua ousadia, vai se construindo na busca por saber quem é, cheio de curiosidade e solidão, que marca sua espera pelo encontro com o outro. Segundo a personagem Maria da Paz: “[...] o que te encerra a boca é outra coisa, Quê, Uma dúvida, uma angústia, um temor [...]. (SARAMAGO, 2002, p.169). 
Portanto, vemos a curiosidade e angústia gerando a ambigüidade de um homem que busca por sua essência, que sempre escapa, não só dele, mas também de seu duplo, principalmente depois da instalação da dúvida de quem seria o original. Temos, assim, o homem inquieto que busca pelas respostas sobre sua origem.

Há outro ditado que marca a presença do destino estabelecido, nos mostrando antecipadamente o que acontecerá com a personagem principal: “[...] nunca jogues as pêras com o destino, que ele come as maduras e dá-te as verdes. [...]" (SARAMAGO, 2002, p.16). A partir disso, encontramos uma personagem que representa um herói trágico, pois tem um oráculo representado por sua mãe que prediz seu destino, e mesmo assim, decide fazer sua própria escolha, sabendo que está além de ser um mero professor de História e que por suas ambições será castigado.

$\mathrm{O}$ romance, portanto, remete à mitologia clássica, em que as moiras determinam o destino do homem, e esse, se cai em desmedida, recebe um castigo cruel. A desmedida de Tertuliano é sua obstinação por encontrar António Claro, seu sósia, e assim como nas tragédias clássicas, o destino desse encontro é anunciado desde o início, pois não há espaço para dois iguais no mundo.

Entretanto, Tertuliano decide se empenhar na investigação de encontrar seu duplo e acaba dando abertura para participação um na vida do outro, conduzindo assim, ao trágico destino. Os dois homens trocam de identidade e quando António Claro morre faz com que Tertuliano tenha que assumir sua vida, morrendo diante da sociedade. $\mathrm{O}$ homem, pois, deveria ficar sempre no caminho do meio, sem ser pacato ou afastado demais, mas também sem se tornar muito investigativo e arrogante.

É interessante notarmos que não só no conteúdo, mas também na forma de seu texto, Saramago retoma os clássicos, utilizando a categoria formal do coro. O coro traz, na tragédia, a opinião do senso comum sobre o conflito trágico e sobre as atitudes do herói, assim, no texto saramaguiano, temos o Senso Comum exercendo exatamente esse papel.

Ao contrário das estruturas tradicionais, em que o coro passa a ser expresso por alguma personagem que é companheira do herói, nesse romance ele vem como Senso Comum, que sendo uma personagem, mostra o tom irônico do autor, pois, recebe o nome da mesma função que desempenha. Além disso, o Senso Comum conversa com o herói e entra em conflito com o mesmo, não sendo companheiro.

[...] a ligação que houvesse entre uma coisa e outra, o senso comum de Tertuliano Máximo Afonso compareceu finalmente a dar-lhe o conselho cuja falta mais se vinha notando desde o aparecimento do empregado da recepção no televisor, e foi esse conselho o seguinte, Se achas 
que deves pedir uma explicação ao teu colega, pede-a de uma vez, sempre será melhor que andares por aí com a garganta atravessada de interrogações e dúvidas, recomendo-te em todo o caso que não abras demasiado a boca, que vigies as tuas palavras, tens uma batata quente nas mãos, larga-a se não queres que te queime[...], pões uma pedra sobre o assunto e acabas com $o$ mistério antes que ele comece a deitar fora coisas que preferirias não saber [...] (SARAMAGO, 2002, p.31).

Na tentativa de ser e agir por si próprio, Tertuliano passa a ser, a todo instante, desafiado pelo Senso Comum, que tenta convencê-lo a deixar o desconhecido como é, não levantando questionamentos, ou seja, sendo um homem prudente diante das novidades para evitar uma tragédia ao final. Entretanto, essa tentativa de manter o equilíbrio é desfeita na medida em que a realidade da vida se impõe a Tertuliano, forçando-o a agir quando se descobre como um erro e se pergunta: "Que é ser um erro?" (SARAMAGO, 2002, p.29).

Com a descoberta do caso de duplicação, a história de Tertuliano passa a ser cheia de indecisões e incertezas e ele, que sempre teve muito cuidado com a vida, a se ver parte do caso, percebe que possui uma vontade dentro de si, própria da alma humana, e tenta se entender.

A busca de entendimento, para saber quem é e de como deve agir, faz com que o homem englobe o outro, o que acaba acontecendo com Tertuliano, fazendo-o descobrir "que o novelo do espírito humano tem muitas e variadas pontas" (SARAMAGO, 2002, p.96) e que "o próprio dele inclina-se mais para o lado da melancolia, do ensimesmamento, de uma exagerada consciência de transitoriedade da vida, de uma incurável perplexidade perante os autênticos labirintos cretenses que são as relações humanas" (SARAMAGO, 2002, p.20032004).

Esse novelo nos remete ao mito de Teseu e o minotauro, em que o herói derrota a criatura monstruosa e consegue sair do labirinto, onde ela habitava, seguindo o caminho que havia marcado com um novelo. No entanto, aqui, Saramago coloca sua personagem, dentro de um labirinto, que seria a própria vida com desafios e problemas, e sua condição de homem diante dela, na busca de se encontrar. Assim, ao ser colocado diante das situações, o homem se tornaria vários, não havendo uma única constituição existencial.

O Abismo, sempre grafado em maiúsculo, e as imagens das estradas estão presentes na vida da personagem principal, "[...] confuso, enredador de labirintos e perdido neles [...]" (SARAMAGO, 2002, p.290) e que fala "[...] de um caminho que deixara de ter princípio" (2002, p.290). Assim, Tertuliano passa a existir projetando-se no outro, tentando compreender a si mesmo. Como se encontra no meio de muitas dúvidas, não sabendo quem é e o que é, a 
personagem apenas tem certeza que a vida dura toda a vida e que o resto é instável, assim como os passos que dá durante o romance.

Assim como nos mitos, também nesse romance temos um tempo cíclico que marca a trajetória da personagem na busca de um sentido para sua vida, principalmente depois de encontrar outro semelhante, busca que não se acaba mesmo depois da morte de António Claro e mostra que a procura do homem por si mesmo não tem fim. Envolto pela solidão, Tertuliano nos apresenta a compreensão do homem que busca o que lhe está destinado, sendo muitas vezes vacilante diante do que lhe é apresentado.

Atentando para o avanço industrial, no qual as relações econômicas se tornam cada vez mais importantes e fazem com que as pessoas percam o sentido de ser, o autor nos coloca diante de uma situação de duplicação do próprio homem. Com isso, mostra que a humanidade está perdendo sua individualidade e empreendendo uma constante busca por si mesma, o que faz retornar a um tempo cíclico. O homem transformado em coisa passa a viver sob o tédio, marcado pela repetição no lugar da originalidade.

A única coisa que Tertuliano e António Claro têm em comum é a imagem, que é vendida pelo segundo como um produto e dá continuidade à fabricação em série, do mundo capitalista, pois ao final, aparece mais um sósia, reforçando assim, a falta de individualidade. Isso nos remete a algo que não tem fim e por isso é cíclico, pois, Tertuliano, ao assumir a vida de António Claro encerra um ciclo, mas inicia outro novamente pela busca de saber quem é realmente, com aparecimento de mais um sósia.

É interessante notarmos que Tertuliano é um homem que não atentava para questões de sua existência e vivia no vazio de sua rotina até a descoberta de António Claro, sendo assim, após se encontrar na imagem do outro, tomado por uma obsessão em saber se é o original. Temos aqui uma intertextualidade com o mito de Narciso, embora, nesse mito o homem, belo, viva até encontrar-se com sua imagem refletida na água, apaixonando-se por ela e definhando até a morte na espera por sua 'amada'.

A aproximação com António Claro, como já dito, é a causa da desmedida de Tertuliano, que na busca por respostas se mostra capaz de ser múltiplo.

Tertuliano Máximo Afonso, até esses dias pacífico professor de História do ensino secundário, demonstra ser dotado de suficiente talento para o exercício de qualquer destas duas actividades profissionais, ou a de disfarçado delinqüente, ou a do polícia que o investiga. Demos nós tempo ao tempo, e saberemos qual das duas vocações prevalecerá. SARAMAGO, 2002, p.165).

Essa duplicidade já se encontra presente no nome da personagem, que mesmo sempre chamada pelo nome inteiro, como sendo única no mundo, se encontra duplicada. Cada um dos 
nomes de Tertuliano Máximo Afonso pode ser visto como nomes próprios independentes e pertencentes a pessoas diferentes, cada uma com uma personalidade, como se a personagem nunca estivesse sozinha.

Saramago, em suas obras, sempre dá uma atenção especial para os nomes, proporcionando nessa obra um sentido para o nome múltiplo que retoma as características post-modernistas de fragmentação do sujeito, não existindo um discurso verdadeiro no mundo complexo. Com isso, percebemos que atualmente é difícil caracterizar o indivíduo com uma característica única, pois ele pode apresentar mais de uma, até mesmo sendo opostas.

Dessa forma, temos o nome Tertuliano, de origem hebraica que significa 'falso ministro' e nos remete à falsidade - questão levantada pelo post-modernismo - questionando a veracidade das afirmações. Com esse primeiro nome, já presente no início do texto, o autor pode querer nos informar de que a personagem seria algo falso, uma cópia.

O primeiro nome é seguido por Máximo, originário do latim com o significado de 'o maior', dando para os leitores duas formas de leitura. A junção com o primeiro nome nos levaria a entender que a personagem seria uma grande falsidade, uma cópia maior. No entanto, também podemos pensar o nome Máximo separadamente, ou seja, a personagem seria 'o máximo', o que não é, pois nos é mostrada como um sujeito medíocre, tornando-se assim, uma ironia.

Afonso é o último nome, de origem germânica e significa caprichoso, cabendo à personagem, que só age por vontade própria, não seguindo os avisos prévios. A personagem maltrata sua namorada, Maria da Paz, além da própria mãe, pois não liga nem vai visitá-la. Mesmo assim, Tertuliano tem todas as suas vontades realizadas, sendo mimado por sua mãe e namorada, que se deixam moldar por seus caprichos.

Podemos estender esse tipo de análise para as outras personagens do romance, como para António Claro, que usa um nome artístico Daniel Santa-Clara, tendo assim, um duplo, mesmo antes de conhecer Tertuliano. Esse indivíduo é por si só uma ficção, tendo seu nome inventado e preferindo que seja denominado como heterônimo faz com que assuma outra personalidade com características próprias de Daniel Santa-Clara.

Além disso, os nomes António Claro e Daniel Santa-Clara sugerem a clareza e a claridade importantes para a compreensão do homem, que acaba sendo prejudicada pela maneira de agir da personagem, sendo vingativa e ambiciosa em relação a Tertuliano, que revela no nome certa grandeza, mas que se mostra fraco diante da situação, chegando a omitir a carta de António Claro e a disputa por Maria da Paz. 
Diante disso, precisamos atentar para outro fato que relaciona Tertuliano e António Claro, e que Saramago coloca em seu texto. Tertuliano Máximo Afonso é professor de história e uma pessoa organizada, enquanto António Claro é mestre do mascaramento por ser ator. Assim, entre eles instala-se um conflito para saber quem é o verdadeiro e quem é o duplicado e falso. Tertuliano, até mesmo enfatiza certa superioridade de sua profissão, desprestigiada, mas fixa, em relação à profissão do outro:

$\mathrm{Eu}$ ao menos sou professor de história, murmurou. Uma declaração assim, que acintosamente tinha pretendido determinar e enfatizar a sua superioridade, não apenas profissional, mas também moral e social, em relação à insignificância do papel da personagem [...] (SARAMAGO, 2002, p.89).

Saramago, assim, usa metalinguagem, colocando as duas personagens como personificação da História e da Literatura: Tetuliano que mantém a ordem cronológica até para assistir os filmes seria a representação da História, António Claro, fazendo suas invenções pode fazer o papel da Literatura. Isso transforma o livro em uma discussão metalinguística sobre a precedência da História sobre a Literatura ou vice-versa.

Essa discussão entre História e Literatura para saber qual discurso veio primeiro também é retratada pelo mesmo questionamento que aparece entre as duas personagens, pois no encontro entre elas o ameaçador passa a ser perseguido pela consciência do 'irmão bastardo' ser o primogênito. No primeiro encontro eles querem ver os documentos para saber quem nasceu primeiro e descobrem que nasceram no mesmo dia, partindo assim, para saber a hora do nascimento que é dito em primeiro lugar por Tertuliano. Esse fato deixando-nos na dúvida se realmente António Claro disse a verdade sobre ter nascido antes ou apenas inventou para se destacar sobre o outro, que antes o ameaçava.

Com isso, Saramago retoma a característica do post-modernismo do uso da metaficção historiográfica, problematizando a veracidade da História. Atualmente, os saberes narrativos precisam de veracidade, pois a quantidade de informação disponível e a facilidade com que são transmitidas fazem com que esses saberes tenham de ser verificados. Essa verificação de autoridade passa para a História, que enquanto narrativa, cria um fato histórico irrecuperável, tendo acontecido no passado.

A partir do que foi dito, percebemos que António Claro, tendo seus papéis secundários no cinema, começa a ganhar mais espaço, assim como a Literatura. A personagem, que vive representando o que poderia ter sido, acaba obrigando Tertuliano a deixá-lo passar uma noite com Maria da Paz, podendo, aqui, ser uma representação da Literatura, que eventualmente, se 
faz passar por História. Assim, precisamos estar muito atentos para reconhecer os enganos provocados pela Literatura, como por exemplo, uma marca de aliança no dedo.

A mão esquerda dele quase lhe encobria o rosto. O dedo anelar mostrava a marca circular e esbranquiçada que as alianças longamente usadas deixam na pele. Maria da Paz estremeceu, julgou que estava a ver mal, que estava a sonhar o pior dos pesadelos, este homem igual a Tertuliano Máximo Afonso não é Tertuliano Máximo Afonso, Tertuliano Máximo Afonso não usa anéis desde que se divorciou, a marca do seu dedo há muito tempo que se desvaneceu. (SARAMAGO, 2002, p.312).

Tertuliano Máximo Afonso ama Maria da Paz, mas só descobre isso depois que ela morre, como se tivesse precisado de um distanciamento para reconhecer o que sentia. Ele é um homem que tem vínculo afetivo forte com a mãe, que prevê o futuro, sendo esse vínculo mais uma ligação entre o professor e a História. Assim, enquanto nos é mostrado que Tertuliano tem certeza de suas origens, nada é mencionado sobre António Claro, como se tivesse surgido do nada, da mesma forma que aparece na vida do primeiro. Dessa maneira, Saramago problematiza a certeza dos fatos e falta de imaginação por parte da História:

[...] o pior defeito do homem, pelo menos desde que o conhecemos, tem sido o excesso de imaginação, na verdade ninguém diria que se trata de um professor de História a quem apenas os factos deveriam interessar, só por ter visto pelas costas a mulher que acaba de passar já o temos aqui a fantasiar identidades, ainda por cima a de uma pessoa a quem não conhece, [...], apesar de sua tendência para o desvario imaginativo, ainda consegue, em momentos decisivos, sobre-por-lhe uma frieza de cálculo que faria empalidecer de ciúme profissional o mais encalecido dos especuladores da bolsa. (SARAMAGO, 2002, p.172-173).

Dessa forma, a História se aproximaria da Literatura através da imaginação, como Tertuliano quando se apossa do lugar de António Claro por vingança, tomando-o definitivamente após a morte do mesmo. Isso simboliza uma das características do movimento post-moderno, em que a metaficção historiográfica ganha espaço na ficção, fazendo, assim, que a História sobreviva disfarçada de Literatura. Essa ideia pode ser verificada no diálogo de Tertuliano com o professor de matemática:

[...] Mas isso não quer dizer que tenha mudado moral e fisicamente a ponto de me parecer a outra pessoa, Eu limitei-me a dizer que você não parecia o mesmo, não que se parecesse a outra pessoa, A diferença não é grande, A nossa colega de Literatura diria que é, pelo contrário, enorme, e ela entende dessas coisas, creio que em subtilezas e matizes a literatura é quase como a matemática, Já eu, pobre de mim, pertenço à área da História, onde os matizes e as subtilezas não existem, Existiriam se a História pudesse ser, digamos assim, o retrato da vida, Estou a estranhá-lo, não é próprio de si ser tão convencionalmente retórico, Tem toda a razão, em tal caso a História não seria a vida, apenas um dos possíveis retratos dela, parecidos, sim, mas nunca iguais. (SARAMAGO, 2002, p. 145-146). 
Assim, constatamos que Saramago segue a proposta post-modernista da necessidade de autenticação dos saberes narrativos, colocando duas personagens que são falsas como sendo representantes da História e da Literatura, que são, por sua vez, ficção e fictício. Verificamos, então que o autor pensa História como Literatura, sendo um relato que segue os fatos, mas também apresenta pontos de inventividade.

Seguindo as análises das personagens, há outra muito interessante que é Carolina, a mãe de Tertuliano, que prediz o destino do filho, e assim, como Cassandra, a personagem de tragédia que retoma, não é escutada.

[...], se queres dou-te um exemplo, não decidir a tempo pode tornar-se em arma consciente de agressão mental contra os outros, Sabia que tinha dotes de psicóloga, mas não que chegasse a tanto, De psicologia não sei nada, nunca estudei uma linha, mas de pessoas creio saber alguma coisa, [...] quando, para sossegar, ele tinha dito que neste mundo tudo se resolve, soavam-lhe agora a vaticínio de desastres, a núncio de fatalidades, como se, em lugar da idosa senhora que se chamava Carolina Máximo e era sua mãe, lhe tivesse saído do outro lado do fio um sibila ou uma Cassandra a dizer-lhe, por outras palavras, Ainda estás em tempo de parar. (SARAMAGO, 2002, p.137)

Notamos, portanto, que diferente de Cassandra, Carolina não tem o dom da premunição, mas sabe o que acontecerá ao filho, porque o conhece da mesma forma que um estudioso da História traça linhas de acontecimentos sobre um evento por ter conhecimento de situações semelhantes, que já aconteceram. Assim, o que temos é uma analogia e um instinto maternal, de quem conhece seu filho, mostrando assim que os homens carecem de medida e contribuem para sua própria destruição.

[...] Há parte de ti que dorme desde que nasceste, e o meu medo é que um dia destes sejas obrigado acordar violentamente, $\mathrm{O}$ que a mãe tem é vocação para Cassandra, [...] A tal Cassandra era filha do rei de Tróia, um que se chamava Príamo, e quando os gregos foram pôr o cavalo de madeira às portas da cidade, ela começou a gritar que a cidade seria destruída se o cavalo fosse trazido para dentro, [...], Os troianos acharam que ela estava louca e não fizeram caso dos vaticínios, E depois, Depois a cidade foi assaltada, saqueada, reduzida a cinzas, Portanto essa Cassandra que tu dizes tinha razão, A História ensinou-me que Cassandra tem sempre razão, [...], Logo, tu és um daqueles troianos que não acreditaram, e por isso, Tróia foi queimada, Neste caso não há nenhuma Tróia para queimar, Quantas Tróias com outros nomes e noutros lugares foram queimadas depois dessa, Inúmeras, Não queiras tu então ser mais uma, Não tenho nenhum cavalo de madeira à porta de casa, E se o tiveres, escuta a voz desta Cassandra velha, não o deixes entrar, [...], não voltes a encontrar-te com esse homem, [...] (SARAMAGO, 2002, p.260)

Essa comparação com Cassandra e a retomada da história de Troia, nos mostra como o autor do romance utiliza a paródia com a história dessa guerra como uma retomada que questiona o texto e não uma sátira. Essa relação também aparece no uso do nome Helena, mulher de António Claro, que na história original, na Ilíada, seria a 'causadora' da guerra, 
enquanto no romance é a personagem que se adapta ao que for mais conveniente, trocando de marido, assim, como Helena de Troia e ficando com Tertuliano quando António morre.

Entretanto, no romance não há guerra entre os homens, Menelau, o marido, e Páris, o apaixonado, por causa de uma mulher, pois existe outra, permitindo uma relação de troca. É interessante notarmos que Maria da Paz, além de elemento de paz é também o de troca, sendo o objeto de desejo de António Claro da mesma maneira que a guerra é o de desejo de Menelau, e não Helena.

Com isso, Saramago reforça a visão de que a guerra de Troia foi movida muito mais por um interesse econômico, do que pelo amor de um marido, em busca também de retomar sua honra, por ter tido a mulher levada de sua casa. Então, assim como no original, em que temos dois objetos de desejo (Helena e a própria guerra), aqui, no romance, existem duas mulheres que são os objetos de desejo de dois homens.

Através dessa retomada do mito feita por Saramago, temos Tertuliano que coloca sempre a parte prática na frente da emoção, não valorizando as mulheres e podendo representar Menelau, já que não é romântico e usa as mulheres para obter o que deseja, assim como utiliza o nome de Maria da Paz para enviar uma carta a Daniel Santa-Clara. Com isso, António Claro seria Páris, tendo muito jeito com as mulheres e seduzindo Maria da Paz, que estando apaixonada não percebe a troca imediatamente.

Essa paródia é feita de maneira sutil e permite a reatualização do mito e a fusão do tempo mítico ao histórico, mostrando as contradições e fragmentação do homem moderno, cercado de aflições, sendo que apenas um leitor atento e com conhecimento prévio é capaz de percebê-la. Ela ainda nos permite fazer uma referência mítica à caixa de Pandora, mostrando o quanto a curiosidade de Tertuliano por António Claro levou ambos ao encontro dos males. Pandora, ao abrir a caixa, lançou os males sobre a terra, mas conseguiu fechá-la antes de deixar escapar a esperança, que no romance saramaguiano é representada por Helena, a personagem que dá a Tertuliano outra chance para uma nova vida.

Portanto, percebemos que o romance em questão trata o tema do duplo como alegoria do problema da humanidade em acabar com a desumanização, colocando em sua estrutura o caráter, as potencialidades e os defeitos humanos, e tornando-se assim, como adverte Saramago, em entrevista à Folha, em 02/11/2002, um romance engajado não muito perceptível à primeira leitura.

A narrativa se passa no tempo atual das grandes metrópoles, mas que não é identificada, podendo ser qualquer lugar em que temos uma sociedade mecanizada onde o homem se tornou parte das máquinas. Assim, o usando o duplo como alegoria, Saramago 
evidencia que as qualidades essenciais da vida tendem a morrer quando ficam estagnadas, sendo válido para o indivíduo o que é válido para a sociedade, pois ambos crescem o declinam, já que não são estáticos.

Esse tema do duplo faz surgir outras contradições presentes na humanidade como: amor e o ódio, eu e o outro, vida e morte, os quais não têm solução fácil apresentada pelo narrador. Esse por sua vez, tenta expressar as possibilidades que vê e, de maneira alegórica, denuncia um espírito destruidor e a atração pela morte e pelo tédio, que dificultam conhecimento do homem por si mesmo. Tertuliano passa a jogar com a morte, a partir da descoberta de seu duplo, sendo algo perigoso e ao mesmo tempo estimulante em relação a sua vida enfadonha.

As personagens de Saramago nos revelam que o homem tem necessidades além de sua sobrevivência. Tertuliano e António Claro, sendo envolvidos pelo sistema, foram transformados em objetos e perderam suas próprias identidades, caminhando para a depressão e despersonalização. Assim, o uso alegórico do duplo nos mostra que o homem deve ser incitado em suas vivências para não se tornar passivo diante da vida.

Mesmo sendo igual, cada um é um ser à parte que pertencem a um círculo individual, reforçado por outras personagens, fazendo com que os duplicados neguem um ao outro. Essa existência remete à despersonalização, apontando para a crise de identidade interna devido a prestígio dado à externa, nos tempos atuais.

A ideia da compreensão do eu não seria acessível às pessoas, sendo duplicadas ou não, entretanto, esse conhecimento só é possível se elas se reconhecerem no outro. Com isso, podemos entender o uso alegórico do duplo como revelador de que o homem é incapaz de perceber que a manutenção de seu ser depende do outro, à medida que esse lhe reconheça a existência. Dessa forma, Tertuliano e António Claro nos mostram o quanto o homem vive só para si, tomando suas direções próprias e revelando suas inquietações diante daquilo que lhe é semelhante.

Com a trajetória dos duplos, constatamos que nada deve ser excluído com base na idéia de originalidade, focando assim, nas diferenças, que são muito mais produtivas do que a igualdade, pois a partir delas é que surge o novo, mesmo sendo releitura do velho. Essa idéia se concretiza na utilização de Saramago pela estética post-moderna de retomada de escolas anteriores com uma nova visão, permitindo ao texto uma gama variada de intertextualidades.

Dessa maneira, o romance de Saramago, se relaciona à tradição e à memória, tornando-se uma construção genérica, que não nos permite a identificação exata de tempo e 
lugar, mas que promove uma abertura para pensarmos a essência do homem, suas contradições e tentativas de interpretações.

\section{Referências}

ARNAUT, A. P. Post-modernismo no romance português contemporâneo: fios de Ariadne, máscaras de Proteu. Coimbra: Almedina, 2002.

BAKHTIN, M. Questões de Literatura e de Estética. São Paulo: Annablume, 2002.

BASTAZIN, Vera. Mito e poética na literatura contemporânea: um estudo sobre José Saramago. Cotia: Ateliê Editorial, 2006.

BRANDÃO, Junito de S. Mitologia Grega. Petrópoles: Vozes, 1993. 3 vols.

CORRÊA, A.A Temas e motivos na Literatura Portuguesa. Londrina: Ed. UEL, 1997.

COSTA, Horácio. José Saramago. O período formativo. Lisboa: Editorial Caminho, 1997.

ECO, Umberto. Obra aberta: forma e indeterminação nas poéticas contemporâneas. São Paulo: Perspectiva, 1991.

ELIADE, Mircea. Mito do Eterno Retorno. São Paulo: Mercuryo, 1992.

FLORY, Suely Fadul Villibor. Texto, contexto e metatexto. O papel catalisador do leitor no discurso ficcional de José Saramago e David Mourão-Ferreira. Tese (Livre Docência em Teoria Literária) - Assis: Universidade Estadual Paulista "Julio de Mesquita Filho", 1994

GUÉRIOS, R.F. Dicionário etimológico de nomes e sobrenomes. São Paulo: Ave Maria, 1981.

HUTCHEON, L. Poética do pós-moderno. Trad. Ricardo Cruz. Rio de Janeiro: Imago, 1991.

LOPONDO, Lílian ; SILVA, Ângela Ignatti. O topos do retorno em Ensaio sobre a cegueira, de José Saramago: tradição e ruptura. In: CORRADIN, Flávia Maria ; JACOTO, Lílian (orgs). Literatura Portuguesa ontem, hoje. São Paulo: Paulistana, 2008. p. 91-116.

MACHADO, Cassiano Elek. José Saramago lança "O homem duplicado". São Paulo: Folha de S. Paulo, 02/11/2002. Entrevista a José Saramago.

MENDONÇA, Fernando. A literatura portuguesa do século XX. São Paulo: HUCITEC, 1973.

NASCENTES, Antenor. Dicionário etimológico da língua portuguesa. Rio de Janeiro:

Acadêmica: Francisco Alves, 1952-1955. 2 vols. 